\title{
Food safety, food fraud and food defense: a fast evolving literature
}

by Manning, L. and Soon, J.M.

Copyright, Publisher and Additional Information: This is the author accepted manuscript. The final published version (version of record) is available via Wiley

Please refer to any applicable terms of use of the publisher.

DOI: $10.1111 / 1750-3841.13256$

Harper Adams

University 


\title{
Food safety, food fraud and food defense: a fast evolving literature
}

\begin{abstract}
Intentional food crime is plural in nature in terms of the types of crime and the differing levels of financial gain. Successful models of food crime are dependent on how well the crime has been executed and at what point, or even if, detection actually occurs. The aim of this paper is to undertake a literature review and critique the often contradictory definitions that can be found in the literature in order to compare and contrast existing food crime risk assessment (FCRA) tools and their application. Food safety, food defense, and food fraud risk assessments consider different criteria in order to determine the degree of situational risk for each criteria and the measures that need to be implemented to mitigate that risk. Further research is required to support the development of global countermeasures that are of value in reducing overall risk even when the potential hazards may be largely unknown and specific countermeasures that can act against unique risks.
\end{abstract}

Keywords: adulteration; fraud; holistic; risk mitigation

Abbreviations: economically motivated adulteration (EMA); Food Crime Risk Assessment Model (FCRA)

\section{Introduction}

Contamination in the context of food can be described as "the introduction or occurrence of an unwanted organism, taint or substance to packaging, food, or the food environment" (BRC, 2015). Food safety hazards have been defined as "a biological, chemical, or physical agent in, or condition of, food with the potential to cause an adverse health effect" (CAC, 2003; BS EN ISO 22000; 2005; Wallace et al. 2011). The United States (US) Federal Food, Drug and Cosmetic Act Section 342 defines adulterated food principally as food that bears or contains: "any poisonous or deleterious substance which may render it injurious to health; but in case the substance is not an added substance such food shall not be considered 
adulterated under this clause if the quantity of such substance in such food does not ordinarily render it injurious to health." Thus an adulterant can be deemed to be any 30 poisonous or deleterious substance. Section 343 of the same legislation defines misbranded 31 food as food that is falsely or misleadingly labeled, offered for sale under another name, is an 32 imitation of another food, where a container is misleading as to the contents. The term 33 adulterated food as described above does not distinguish explicitly between intentional or 34 unintentional addition of an adulterant. Lipp (2011) stated that to differentiate between the 35 terms contamination and adulteration, and by inference contaminant and adulterant, the 36 former should be considered in terms of unintentional activity and being technically unavoidable, whilst adulteration is intentional replacement of an ingredient that is specifically motivated e.g. for economic or ideological gain.

It should be considered that although the terms contamination and malicious contamination have been used widely in the literature, some US literature distinguishes between contamination and adulteration in that the former is used to describe instances of 42 unintentional contamination whilst the latter term is used to define all intentional activities 43 whether motivated for economic gain (EMA) or not. In this paper if literature is quoted that has described an event as contamination, whereas the US definition would define it as adulteration, for purposes of accuracy to the original source that term has remained in the text. However, consideration should be given going forward when developing supply chain 47 standards and regulations to ensure common terminology use as this would be of value.

48 Whilst historically food safety was described as the concept that food will not cause harm to 49 the consumer when it is prepared and/or eaten according to its intended use (BS EN ISO 5022000,2005 ) i.e. a term encompassing both (a) intentional acts and (b) unintentional 51 contamination, more recent literature seeks to differentiate between the two. PAS 96 (2014) 52 defines a hazard as something that can cause loss or harm which arises from a naturally 
53 occurring or accidental event or results from incompetence or ignorance of the people

54 involved compared to a threat being something that can cause loss or harm which arises from

55 the ill-intent of people. FSIS (2014) characterizes food safety and food defense as being

56 distinct issues that need to be addressed namely that food safety refers to protecting the food

57 supply from unintentional contamination whereas food defense refers to protecting the food

58 supply from intentional adulteration with a motive to cause harm. Alternatively the Global

59 Food Safety Initiative (GFSI, 2013) suggests that food defense is a sub-set of food safety

60 issues (where the adulterant has the potential to cause harm and separate where the agent is

61 non-harmful rather than the FSIS definition of them being a separate set of issues.

62 The potential for food crime is often influenced by a difference between availability and

63 demand creating an opportunity for criminals or fraudsters to financially benefit from the

64 shortfall. The World Food Summit of 1996 defined food security as existing "when all people

65 at all times have access to sufficient, safe, nutritious food to maintain a healthy and active

66 life" (WHO, nd). Defra (2006) goes further and defines levels of food security as: individual

67 or household food security relating to purchasing power which is determined by income,

68 access to resources, and affordability of food; regional food security where regions are

69 dependent on key distribution routes for food; national/trading block food security relates

70 to the ability of a country or trading block to assess sufficient foodstuffs, even in the face of

71 severe disruptions to the supply chain; and global food security i.e. the ability of the world's

72 food producers to meet global demand, and ensure the efficiency and effectiveness of global

73 trading and distribution systems. The interconnecting factors that frame food security also

74 influence the opportunities for food crime.

75 Crime is defined as an offence or illegal acts punishable by law. The term "illegal" can be

76 considered as being unlawful, contrary to law or an activity which the law directly forbids

77 (Rapalje and Lawrence, 1997). Food crime can be described as an activity organized by 
78 individuals or groups who knowingly set out to deceive, and or injure, those purchasing and 79 consuming food (adapted from Elliott Review, 2014). This rationale would suggest that food 80 crime occurs when food is intentionally modified in order to bring harm to individuals or for 81 purposes of economic gain and both situations may lead to issues of food safety or food 82 quality. Two brothers who owned and operated Jensen Farms in Colorado pled guilty to 83 charges associated with the introduction of cantaloupe adulterated with Listeria 84 monocytogenes rendering the product injurious to health into interstate commerce (FDA, 85 2013). Thus it was determined that the cantaloupe bore a poisonous substance that rendered 86 them injurious to health. In May of 2011 the Jensen brothers allegedly changed their 87 cantaloupe cleaning system. The new system, built to clean potatoes, was installed, and was to include a catch pan to which a chlorine spray could be included to clean the fruit of bacteria. The chlorine spray, however, was never used. In this example the term adulteration is suggests that by intentionally failing to implement a process that is specifically designed to

91 minimize the risk of harm to consumers then a criminal act has taken place.

92 Fraud can simply be described as: a type of criminal activity that can be an abuse of position, 93 or false representation, or prejudicing someone's rights for personal gain (SFO, nd). Food 94 fraud is defined by the Food Standards Agency (FSA) as: "deliberately placing food on the 95 market, for financial gain, with the intention of deceiving the consumer" (Elliott Review, 96 2014). The Elliott Review (2014:6) states that "food fraud becomes food crime when it no 97 longer involves random acts by 'rogues' within the food industry but becomes an organised 98 activity by groups which knowingly set out to deceive, and or injure, those purchasing food" 99 thus building on the FSA definition.

100 The US Food and Drug Administration (FDA) determine economically motivated 101 adulteration (EMA) as "the fraudulent, intentional substitution or addition of a substance in a 102 product for the purpose of increasing the apparent value of the product or reducing the cost 
103 of its production", i.e., for economic gain (Lutter, 2009). EMA is therefore only one example

104 of the types of fraudulent activity that can occur in the food supply chain and EMA as a

105 definition should not be used when considering other types of fraudulent activity. This is

106 discussed more fully later in the paper. The aim of this research is to undertake a literature

107 review and critique the often contradictory definitions that can be found in the literature in

108 order to compare and contrast existing food crime risk assessment (FCRA) tools and their use.

109 The use of the term FCRA is novel and not currently used in the literature and as such is an

110 evolving concept. Whilst Elliott (2014) proposed the use of food crime prevention networks

111 FCRA build on this as they contain two distinct elements as is described in this paper. Firstly

112 there is the risk assessment process itself and then the development of a series of

113 countermeasures that are embedded in a food control system at organizational or national

114 levels. Thus adopting Felson's approach (2006) of identifying events, sequences and settings

115 is helpful in developing food crime risk assessment models.

116 The methodological approach that has been used in terms of critiquing existing academic and

117 gray literature is of value to academics and practitioners to clarify the current contradictions

118 in the literature and to develop a common, accepted vocabulary that is then utilized going

119 forward in the food industry. This element of redefinition will also inform future reviews of

120 regulatory standards and also global standards such as those developed through Codex

121 Alimentarius and the International Standards Organization (ISO).

\section{2. Food defense}

123 Food defense is the collective term used to describe activities associated with protecting the

124 nation's food supply from deliberate or intentional acts of contamination or tampering (FDA,

125 2014). Food defense therefore encompasses intentional contamination (perhaps better phrased

126 as adulteration) of the food supply contrasting with the unintentional contamination that is the

127 focus of established food safety measures (Mitenius et al. 2014). The authors suggest that the 
128 concept of intentional adulteration as being separate from unintentional contamination

129 introduces the notion of a different set of vocabulary such as perpetrator, malicious intent and 130 capabilities. Further, food defense has been described as the process to ensure the security of 131 food and drink and their supply chains from all forms of intentional malicious attack 132 including ideologically motivated attack leading to contamination or supply failure (GFSI, 133 2013). This definition suggests that the term food defense is not only used to define national 134 strategy towards intentional food adulteration, but also can be used at the supply chain and 135 organizational level. Indeed BRC (2015) considers food defense as the procedures adopted to 136 assure the safety of raw materials and products from malicious contamination or theft. 137 Therefore, food defense has been said to reflect the protection activities, and/or the security 138 assurance process or procedures that deliver product safety with regard to intentional acts of 139 adulteration. These policies, processes and procedures will be defined in this paper as 140 countermeasures (see Section 3). Countermeasures are the means and mechanisms 141 implemented to mitigate risk and as a phrase widely used in criminology literature.

142 Food defense strategies can therefore be implemented at national and local levels. The FDA 143 (2015) has differentiated between national risk assessment models and supply chain or 144 organizational food defense models. At national strategy level, in the US the CARVER+ 145 Shock method has been adopted where the acronym CARVER stands for: Criticality - a 146 measure of the public health and economic impacts of an attack as a result of the batch size or 147 network of distribution; Accessibility - the ability to gain physically access and egress where 148 this can change over time and also as a result of the use of counter-measures; Recuperability 149 - the ability of food system to recover from an attack; Vulnerability - the ease of 150 accomplishing the attack. This too can change over time and as a result of the use of counter151 measures; Effect - the amount of direct loss from an attack as measured by loss in 152 production; Recognizability - the ease of identifying the target, with Shock a combined 
153 measure of the health, psychological, and collateral national economic impacts of a

154 successful attack on the target system being the final element (FDA, nd).

155 A vulnerability assessment (VA) tool can be developed to operate at the food facility or 156 individual food process level. The VA tool specifically focuses on three elements that reflect

157 the vulnerabilities that exist and the means for their mitigation for an organization that could 158 potentially be under threat namely the attributes: Criticality, Accessibility, and 159 Vulnerability. This approach is sometimes referred to as Vulnerability Analysis Critical 160 Control Point or VACCP. The FDA and the US Department of Agriculture (USDA) adapted 161 CARVER+ Shock to also develop a vulnerability assessment software (VAS) tool that can be 162 used at food facility or process level in order to build a food defense plan (FDA, 2015). The 163 food defense plan approach supports food business operators to develop personalized food 164 defense plans by integrating existing FDA tools, guidance, and resources into one single 165 application (FDA, 2015). Therefore a situational and premises focused food defense plan can 166 be established to address the risk of intentional food adulteration.

167 Situational risk has been explored within criminology literature (McGloin et al. 2011; Perline 168 and Goldschmidt 2004). Situational risk factors, are often predictive, lie outside of the 169 individual and include environmental factors such as corporate culture, work environment and 170 can have a multiple compounding impact (Perlite and Goldschmidt, 2004: Carson and Bull, 171 2003) and such risk can be reduced by strengthening environmental resilience to mitigate 172 such risk (Clapton, 2014). Therefore, situational crime prevention seeks to reduce 173 opportunities for specific categories of crime by increasing the associated risks and 174 difficulties and reducing the rewards (Clarke, 1995) so situational crime prevention in terms 175 of deterrence of food crime and reduction of crime risk is an important consideration (Spink 176 and Moyer, 2011). 
177 Crime vulnerability can be defined as the extent to which an individual, organization, supply 178 chain or national food system is at risk from, or susceptible to, attack, emotional injury or 179 physical harm or damage from an intentional act. The WHO (2002) suggested that 180 vulnerability should be assessed on the basis of the scientific, economic, political and social 181 circumstances of a country to measure the extent of the threat and to set priorities for 182 resources. The WHO further note that vulnerability should be assessed as a multidisciplinary 183 activity, with input from legal, intelligence, medical, scientific, economic and political sectors 184 (Manning et al. 2005). On a national level vulnerability may be assessed on the basis of a 185 number of factors (Table 1). Further, the determined level of vulnerability needs to be 186 routinely reassessed to ensure that the ranking and prioritization of risk remains appropriate 187 and that suitable countermeasure(s) continue to be in place.

\section{Take in Table 1}

190 Independently PAS 96 (2014) has been developed as a standard to underpin the Threat 191 Analysis Critical Control Point (TACCP) approach to assessing the risk associated with such 192 threats. PAS 96 (2014) describes TACCP as the systematic management of risk through the 193 evaluation of threats, identification of vulnerabilities, and implementation of controls to 194 materials and products, purchasing, processes, premises, distribution networks and business 195 systems by a knowledgeable and trusted team with the authority to implement changes to 196 procedures. TACCP has been designed to interface with and build upon food safety risk 197 management methodology such as hazard analysis critical control point (HACCP) as many 198 precautions taken to assure the safety of food, are likely to also deter or detect deliberate acts 199 of contamination (PAS 96, 2014). TACCP uses a matrix type approach to identify the 200 likelihood of an incident occurring and how it might be mitigated through the use of 201 appropriate countermeasures. This approach is only of value where potential threats and the 
202 risk associated with them can be assessed so it is of little value in mitigating against emerging 203 issues when as previously outlined the modus operandi is for the crime to continue 204 undetected.

\section{3. Food fraud and wider food crime}

206 Most food fraud cases are not harmful, but notable exceptions include the melamine in 207 Chinese skimmed milk powder (Gossner et al. 2009), sudan dyes in spices (Stiborova et al. 208 2002), false labeling of puffer fish as monkfish (Cohen et al. 2009) and the plasticizer di (2209 ethylhexyl) phthalate (DEHP) being used as a cheaper substitute of clouding agents in food 210 and beverages (Yang et al. 2013). Different types of food fraud generate various levels of 211 monetary gains, dependent on how well the 'fraud' has been carried out, and if detection 212 occurs and form an element of wider food crime. Spink and Moyer (2011) proposed seven 213 types of food fraud: namely adulteration, counterfeit product, diversion of products outside of 214 intended markets, over-run, simulation, tampering and theft (Table 2).

\section{Take in Table 2}

217 Criminal attributes can also be characterized into ideological, occasional, occupational, 218 professional and recreational types (Spink et al. 2013). PAS 96 (2014) using a different 219 approach identifies a number of threats that need to be considered when undertaking TACCP 220 namely: EMA, malicious contamination, extortion, espionage, counterfeiting and cybercrime 221 with an associated typology for individuals that pose a threat:

222 - The extortionist.

223 - The opportunist.

224 - The extremist.

225 - The irrational individual.

226 - The disgruntled individual. 
227

- The hacktivist and other cyber criminals.

- The professional criminal.

This extends beyond the product-orientated types of food fraud to consider wider organizational fraud associated with accounting, organizational "secrets" e.g. recipes, unique processing standards etc. When seeking to mitigate supply chain fraud assessment activities must consider countermeasures that are implemented at the supply chain level not just at the facility level. This parallels with the procurement requirement for the adoption of prerequisite programs such as good agricultural practice by suppliers that are designed to prevent food safety issues from occurring in the first place rather than focusing on activities within a site-HACCP plan for detection at facility level as the predominant level of control.

Criminology and understanding of behavioral science provides a wider insight into the motivation and causation behind food crime. This research has considered the extent to which food fraud and food defense fit into these theoretical criminological frameworks (Table 3). Table 3 considers six crime motivation theories and shows the difference between traditional HACCP style risk assessment and the type of assessment that needs to be included in approaches such as TACCP and VACCP. Using HACCP whilst the cause of a food safety hazard is considered in terms how the hazard can arise in order to implement an appropriate preventive measure the mindset of the perpetrator or the incentives to intentionally contaminate have not been explicitly addressed. Furthermore if there is an argument that food safety, food fraud and food defense need to be risk assessed separately there is no requirement to include intentional food adulteration during the HACCP process. Food defense needs to consider the perpetrator, the relevance of impact and their motivation to cause harm. Food fraud is driven by singular motivation i.e. the desire for gain and in order to implement appropriate countermeasures the motivational element of food fraud needs to be fully understood. 


\section{Take in Table 3}

253

254 The magnitude of harm caused by intentional adulteration in terms of likelihood and severity 255 will increase according not only to the agent used, but also if an individual can operate 256 unnoticed in an organization or operates in collaboration with the organization. The degree of 257 mitigation achieved by implementing appropriate countermeasures will vary by type of crime 258 and by the commitment of the management of the organization to minimize vulnerability to 259 crime (Table 4). Seven types of criminal are outlined in Table 4 from the ideologically 260 motivated individual to those who see crime as a recreational activity for entertainment and 261 amusement, occasional criminals that are opportunist and commit crime infrequently, 262 occupational criminals who are active within their place of employment and professional 263 criminals who fund their lifestyle completely from criminal activity. The magnitude of risk 264 (in terms of likelihood and severity) is considered in Table 4 and will be unique to the 265 situation that arises. Typical countermeasures have been described for different types of 266 criminal that need to be considered within an effective food control program.

267 This complexity is shown further in Table 5, and by using a slight modification of the 268 questioning (5 Whys see Motarjemi and Wallace, 2014) technique of root causes analysis 269 firstly food fraud and then food defense with regard to both internal employees and external 270 agents and the risk of intentional food adulteration is considered. The root cause analysis 271 demonstrates that a proactive approach to improving work and supply chain related practices 272 and that focus on intentional adulteration i.e. countermeasures and the utilization of FCRA 273 tools to determine vulnerability is essential in order to mitigate risk.

\section{$274 \quad$ Take in Tables 4 and 5}

275 
276 This argument extends as shown in Tables 4 and 5 to the development of measures to mitigate 277 risk developed as a result of using threat or vulnerability analysis tools. Mitigation measures 278 or countermeasures are designed not only to lessen the impact, but also to make intentional 279 contamination less likely in the first place (Mitenius et al. 2014). Countermeasures developed 280 to minimize food crime risk can include: the use of unique serial numbers at batch, product or 281 lot level; traceability through measures such as Radio Frequency Identification Devices 282 (RFID), and features on the packaging of individual items such as special inks, holograms, 283 etc. on cases of product or on each pallet (Spink et al. 2010). HACCP as a risk assessment 284 tool was developed initially to consider contamination in its entirety both intentional and 285 unintentional a differentiation between the terms food safety and food defense would mean 286 that this may have to be revisited especially in light of an organization using a combination of 287 HACCP, VACCP and TACCP as risk assessment tools. A HACCP approach considers the 288 development of an operational pre-requisite program (OPRP). An OPRP is identified within 289 hazard analysis approaches as essential in order to control the likelihood of introducing food 290 safety hazards and/or the contamination or proliferation of food safety hazards in the 291 product(s) or in the processing environment (BS EN ISO 22000: 2005). Further the 292 development of an OPRP alongside the integration within an organizational management 293 systems of an effective portfolio of food crime countermeasures is of great importance when 294 considering the degree of risk associated with both adulteration and unintentional 295 contamination in a given operational situation.

296 The Global Food Safety Initiative (GFSI) position paper on mitigating the public health risk 297 of food fraud (July 2014) considers the interaction of food defense, food fraud, food safety 298 and food quality. This approach does not clearly separate food safety, food quality, food 299 defense and food fraud but this may simply be a causal result of using a Venn diagram to 300 pictorially describe the interaction. This overlapping representation is in contrast to FSIS 
301 (2014) and the FAO Assuring Food Safety and Quality: Guidelines for Strengthening

302 National Food Control Systems publication (2003:3) that states that:

303 "Food safety refers to all those hazards, whether chronic or acute, that may make food

304 injurious to the health of the consumer. It is not negotiable. Quality includes all other attributes that influence a product's value to the consumer".

306 The FAO (2003) publication places particular importance on the fact that the clear distinction 307 between food safety and food quality and this has public policy implications and also 308 implications for the development of organizational management systems. Thus this separating 309 of terminology can be extended to the organizational development of food safety, food 310 defense and food quality plans, and determining their purpose in terms of what factors they 311 are seeking to control. Therefore the four elements of a food control system, otherwise 312 determined as the four elements of food protection (see Spink and Moyer, 2011) can be 313 described as follows:

- Food defense - ideologically motivated intentional adulteration that makes the food injurious to health.

- Food fraud - economically motivated intentional adulteration that may or may not make the food injurious to health. Thus some food fraud issues may overlap with the definition of food defense whilst others may be a food quality issue.

- Food safety - unintentional contamination of food that makes the food injurious to health; and

- Food quality - delivery of attributes that influence a product's value to consumers.

323 (i) that of Spink and Moyer (2011) where they identified the four elements described above, 324 as being distinct i.e. no food fraud overlap between food quality and food safety (see Figure 325 2) and (ii) that of GFSI (2014) where all four terms are seen as overlapping. 


\section{Take in Figures 1 and 2}

327 The rationale for determining the four elements food safety, food defense, food fraud and

328 food quality as highlighted in this research is important when developing either a national or 329 an organizational food control system.

Increasingly there is a requirement to consider a more holistic approach that encompasses not 333 only scientific criteria, but also aspects of social science in order to risk assess adulteration. 334 Six of the existing FCRA models have been compared (Table 6) in terms of their aims, 335 mechanisms of operation and practicalities of use. Table 6 highlights the value of each model in different situations. The ability to actually quantify the likelihood of a threat or vulnerability in a given situation is in many ways influenced by the degree of adoption of countermeasures and their effectiveness.

\section{Take in Table 6}

The standard BS EN ISO 31000: 2009 - Risk management: principles and guidance provides

341 principles, framework and a process for managing risk. The standard defines uncertainty (or 342 lack of certainty) as a state or condition that involves a deficiency of information and leads to 343 inadequate or incomplete knowledge or understanding. In the context of risk management, 344 uncertainty exists whenever the knowledge or understanding of an event, consequence, or 345 likelihood is inadequate or incomplete. Once determined, BS EN ISO 31000: 2009 provides a 346 hierarchy of how risk should be dealt with:

347 1. Avoiding the risk by deciding not to start or continue with the activity that gives rise $348 \quad$ to the risk;

349 2. Accepting or increasing the risk in order to pursue an opportunity; 
3. Removing the risk source;

4. Changing the likelihood;

5. Changing the consequences;

6. Sharing the risk with another party or parties (including contracts and risk financing); and

7. Retaining the risk by informed decision.

356 HACCP too develops a hierarchy for assessing and mitigating food safety risk (CAC, 2003)

357 the so called seven principles of HACCP:

358 PRINCIPLE 1 Conduct a hazard analysis.

359 PRINCIPLE 2 Determine the Critical Control Points (CCPs).

360 PRINCIPLE 3 Establish critical limit(s).

361 PRINCIPLE 4 Establish a system to monitor control of the CCP.

362 PRINCIPLE 5 Establish the corrective action to be taken when monitoring indicates that a 363 particular CCP is not under control.

364 PRINCIPLE 6 Establish procedures for verification to confirm that the HACCP system is 365 working effectively.

366 PRINCIPLE 7 Establish documentation concerning all procedures and records appropriate to 367 these principles and their application.

368 In order to develop a food safety control system CCPs are identified using qualitative, semi369 quantitative or quantitative means of assessment. Matrices, scoring systems and decision trees 370 are commonly used to identify specific CCPs and mechanisms to eliminate or reduce risk to 371 an acceptable level. The degree of uncertainty is difficult to determine absolutely so semi- 
372 quantitative mechanisms are often used. This approach is also favored with TACCP to 373 determine threats and vulnerabilities. The TACCP approach considers the following questions 374 (PAS 96, 2014):

3751 . Who might want to attack us?

376 2. How might they do it?

377 3. Where are we vulnerable?

378 4. How can we stop them?

379 The threat assessment uses a similar semi-quantitative matrix approach, but despite the name 380 CCPs are not identified as TACCP is more of a threat prioritization system based on the 381 presence or absence of appropriate countermeasures. The Carver+ Shock or CAV approach of 382 VACCP again uses a semi-quantitative scoring approach through a scoring system without 383 defining CCPs specifically. Marsh (2015) suggests that VACCP and TACCP must be 384 undertaken simultaneously so an organization can have a clear picture of both threats and 385 vulnerabilities. Instead of using CCPs, Marsh (2015) decided to use Vulnerability and Threat 386 Points (VTP) as a mechanism for prioritizing risk. In another approach, the NSF Fraud 387 Protection Model can be used to assist organizations to 'think like a criminal' - particularly in 388 assessing vulnerability from the perspective of what is advantageous to the fraudster (NSF, 389 2015). Hence, the model was based on the assumption that fraudsters tend to target food 390 products of higher value where the adulteration is difficult to detect. This can be used to 391 create a hierarchy of low medium and high food fraud risk scenarios (Figure 3).

392 Take in Figure 3

393 Six models have been analysed TACCP, VACCP, the food protection risk matrix (Spink and 394 Moyer, 2011), the food fraud model (NSF, 2014), the USP Preventive Food Fraud 395 Management System and the CARVER + Shock Tool (FDA, 2014). The mechanisms 
396 employed are ones of semi-quantitative risk assessment using prioritization matrices or

397 weighted scoring systems. This approach is often weakened by the degree of uncertainty as to

398 the exact nature of the threat and its likelihood of occurrence. This means that "unknown"

399 threats cannot be mitigated using this approach alone. The most important element of FCRA

400 is the development of a holistic hierarchy (adapted from BS EN ISO 31000: 2009) of how

401 risk should be mitigated:

402 1. Avoiding the risk by ceasing activity or removing the source (only of value with risks 403 that can be quantified);

4042 . Avoiding the risk by not commencing the activity (only of value with risks that can be 405 quantified);

3. Reducing the risk by implementing countermeasures to reduce the likelihood of occurrence (this approach can address both known and unknown threats where they are controlled by the same countermeasure);

4. Sharing the risk with another party or parties including contracts, insurance and risk financing - again this of limited value if a threat and its potential impact cannot be quantified; and

5. Retaining the risk or accepting the level of risk by informed management decision

414 In many cases there is a requirement at national or organizational level for informed decision 415 making with regard to degree of risk that is also centered on the balance between cost and 416 benefit derived which is often difficult to determine in the case of unknown or un-quantified 417 threat.

\section{Conclusion}

419 The aim of this research is to undertake a literature review and critique the definitions that can 420 be found in the literature in order to compare and contrast existing FCRA models and their 
421 application. Figure 1 has been developed to demonstrate the clear distinction between food 422 safety, food quality and food defense and the overlapping nature of food fraud incidents 423 depending on whether the intentional criminal activity has the potential to cause harm or 424 impact on product quality. This builds on existing literature by clearly differentiating what is 425 and is not included in terms of threat, or as in food safety defined as a food safety hazard, i.e. 426 the cause and then how the effect before and after countermeasures have been implemented is 427 quantified when undertaking a VACCP, TACCP or HACCP assessment. The challenge is that 428 the distinction between a potential threat (hazard) and the consequences (effect) should it 429 arise, and the difference between adulteration and unintentional contamination of food and 430 thus the associated countermeasures that should be adopted, is not always fully appreciated by 431 individuals at the facility level who are involved in developing an overarching food 432 protection/control system. This is an organizational weakness that can then lead to the 433 implementation of an adequate food protection/control system which is of little value to the 434 organization in mitigating threat. Intentional food crime is plural in nature in terms of the 435 types of crime and the differing levels of financial gain. This can also be said in terms of the 436 multiplicity of definitions of food safety, food defense, food fraud and food quality found in 437 both academic and gray literature. This plurality creates confusion and multiple 438 interpretations when FCRA is adopted and implemented. In further iterations of regulations, 439 standards and industry protocols increasing harmonization will benefit the industry in 440 developing cohesive food protection/control programs that address all four elements described 441 in this paper and clearly differentiate between contamination and adulteration. Successful 442 modes of food crime are dependent on how well the crime has been carried out and at what 443 point, or even if, detection actually occurs. BS EN ISO 31000: 2009 provides a hierarchy of 444 how risk should be dealt with including avoiding, accepting or retaining risk. Appropriate 445 countermeasures should be adopted as a result of the use of an FCRA model and reassessment 
446 to either remove the risk source; change the likelihood of the risk or the consequences should

447 it occur, sharing or spreading the risk or retaining but monitoring the risk on an ongoing basis.

448 Further research is therefore required to support the development of global countermeasures

449 over and above the critique in Table 4. A framework of countermeasures that are developed in 450 consort with FCRA activities is of value to any organization as has been demonstrated with 451 the development of OPRP to address potential hazards and mitigate food safety risk at facility 452 and supply chain levels.

453

454

455

456

457

458

459

460

461

462

463

464

465

466

467

468

469

470

471

472

473

474

475

476

477

478

479

480

481

482

483

484

485

486

487

\section{References}

BRC (2015), British Retail Consortium Global Standard Food Safety. Issue 7. BRC, London. BS EN ISO 22000:2005, Food Safety management systems - Requirements for any organization in the food chain, BSI London.

BS ISO 31000, Risk management - Principles and guidelines BSI London

CAC (Codex Alimentarius Commission) (2003), Hazard Analysis and Critical Control Point (HACCP) System and Guidelines for its application, Codex Alimentarius Commission Food Hygiene Basic Texts (Revision 4). Available at: http://www.codexalimentarius.org [Accessed on: 15the October 2015]

Carson, S. and Bull, R. (2003), Handbook of Psychology in Legal Contexts, John Wiley \& Sons.

Clapton, W. (2014), Risk and Hierarchy in International Society: Liberal Interventions in the Post-Cold War Era. Palsgrave Macmillan

Clarke, R.V. (1995), Situational Crime Prevention, Crime and Justice Vol. 19, Building a

Safer Society: Strategic Approaches to Crime Prevention (1995), pp. 91-150

Cohen, N. J., Deeds, J. R., Wong, E. S., Hanner, R. H., Yancy, H. F., White, K. D., Thompson, T. M., Wahl, M., Pham, T. D., Guichard, F. M., Huh, I., Austin, C., Dizikes, G. and Gerber, S. I. (2009). Public health response to puffer fish (Tetrodotoxin) poisoning from mislabeled product, Journal of Food Protection 72(4): 810-817

Cohen, L. and Felson, M. (1979). Social change and crime rate trends: a routine activity approach. American Sociological Review 44(4): 588-608.

Croall, H. (2009). White collar crime, consumers and victimization, Crime, Law and Social Change, 51: 127-146 
488 Defra (2006) Food Security and the UK: An Evidence and Analysis Paper. Food Chain 489 Analysis Group. Defra. December 2006

490

491

492

493

494

495

496

497

498

499

500

501

502

503

504

505

506

507

508

509

510

511

512

513

514

515

516

517

518

519

520

521

522

523

524

525

526

527

528

529

530

531

532

533

534

535

Elliott Review (2014), Elliott Review into the Integrity and Assurance of Food Supply

Networks - Final Report A National Food Crime Prevention Framework. HM Government

July 2014. London.

FAO (2003), Assuring food safety and quality: Guidelines for strengthening national control systems. FAO Food and Nutrition Paper 76. ISBN 0254-4725

FDA (2015) Vulnerability Assessment Software. Available at:

http://www.fda.gov/Food/FoodDefense/ToolsEducationalMaterials/ucm295900.htm\#whatme an [Accessed on: 15/10/15]

FDA, (2014), US Food and Drug Administration, Food Defense Acronyms, Abbreviations \& Definitions, Available at:

http://www.fda.gov/food/fooddefense/toolseducationalmaterials/ucm296330.htm [Date accessed 07 October 2015]

FDA (2013) Eric and Ryan Jensen Plead Guilty to all Counts of Introducing Tainted Cantaloupe into Interstate Commerce Available at:

http://www.fda.gov/ICECI/CriminalInvestigations/ucm373174.htm [Date accessed 04

January 2016]

FDA (nd) Vulnerability Assessments of Food Systems Final Summary Report June 2009 February 2012 Available at:

http://www.fda.gov/downloads/Food/FoodDefense/UCM317547.pdf [Accessed on: 15/10/15]

US Federal Food, Drug and Cosmetic Act, Section 342 Available at:

https://www.law.cornell.edu/uscode/pdf/uscode21/lii_usc_TI_21_CH_9_SC_IV_SE_342.pdf

[Accessed 28.12.15]

US Federal Food, Drug and Cosmetic Act, Section 342 Available at:

https://www.law.cornell.edu/uscode/pdf/uscode21/lii_usc_TI_21_CH_9_SC_IV_SE_343.

[Accessed 28.12.15]

Felson, M. (2006), The ecosystem for organized crime, Heuni paper No 26.

FSIS (2014), FSIS Food Safety and Food Defense - Information for In-Commerce Firms, May 2014 USDA Available at:

http://www.fsis.usda.gov/wps/wcm/connect/86cc4d8e-c963-4be2-936a-745e2da9063a/fooddefense-incommerce-firms.pdf?MOD=AJPERES [Accessed on: 15/10/15]

GFSI (2014), GFSI Position on mitigating the public health risk of food fraud. July 2014. Available at: http://www.mygfsi.com/news-resources/news/295-gfsi-position-paper-onmitigating-the-public-health-risk-of-food-fraud.html [Accessed on: 15/10/15]

GFSI (2013), The Global Food Safety Initiative GFSI Guidance Document. Version 6.3. October 2013 
537 Gossner, C.M., Schlundt, J., Embarek, P.B., Hird, S., Lo-Do-Wong, D., Beltran J.J.O., Teoh, 538 K.N., and Tritscher, A., (2009) The Melamine Incident: Implications for International Food 539 and Feed Safety Environ, Health Perspect. 2009 December; 117(12): 1803-1808.

540

541

542

543

544

545

546

547

548

549

550

551

552

553

554

555

556

557

558

559

560

561

562

563

564

565

566

567

568

569

570

571

572

573

574

575

576

577

578

579

580

581

582

583

584

585

586

Hirschauer, N. and Zwoll, S. (2008). Understanding and managing behavioural risks: the case of malpractice in poultry production. European Journal of Law and Economics 26: 27-60

Hirschi, T. (1969). Causes of delinquency. Berkeley: University of California Press.

Leathers, R. (2014). Guideline no. 72. TACCP Threat assessment and critical control point: A practical guide. Chipping Campden: Campden BRI, pp. 1-96.

Lipp, M. (2011), A closer look at chemical contamination. Available at: http://www.foodsafetymagazine.com/magazine-archive1/augustseptember-2011/a-closer-

look-at-chemical-contamination/ Accessed on $28^{\text {th }}$ December 2015

Lutter, R (2009), Addressing challenges of economically motivated adulteration. Available from: www.fda.gov/downloads/newsevents/meetingsconferencesworkshops/ucm163631.ppt

Accessed on $28^{\text {th }}$ December 2015

Manning L., Baines, R.N. and Chadd, S.A. (2005), Deliberate contamination of the food supply chain, British Food Journal, 107 (4) 225-245.

Marsh, K. (2015). BRC Newsletter 10. TACCP and VACCP demystified! Available from: http://www.techni-k.co.uk/Newsletter_10 Date accessed 24 September 2015

McGloin, J.M., Sullivan, C.J., and Kennedy, L.W., (2011), When Crime Appears: The role of emergence. Routledge

Mitenius, N., Kennedy, S.P. and Busta, F.F. (2014), Chapter 35 - Food Defense, Food safety management: A Practical Guide for the Food Industry, (2014), 937-958.

Motarjemi, Y. and Wallace, C. A. (2014). Food safety assurance systems: Root cause analysis of incidents. In, Y. Motarjemi (Ed.). Encyclopedia of Food Safety Vol. 4 Food Safety Management. San Diego, CA: Academic Press, 331-339.

NSF Safety and Quality UK Ltd. (2014). Risk modelling of food fraud motivation - "NSF Fraud Protection Model" intelligent risk model scoping project. FS 246004. Available from: https://www.food.gov.uk/sites/default/files/NSF\%20Final\%20report.pdf Date accessed 7 October 2015.

PAS 96 (2014), Guide to protecting and defending food and drink from deliberate attack. BSI London

Pease, K. (2006). Rational choice theory. In, McLaughlin, E. and Muncie, J. (eds.). The Sage Dictionary of Criminology. London: Sage.

Perline, I.H and Goldschmidt, J. (2004), The Psychology and Law of Workplace Violence: A Handbook for Mental Health Professionals and Employers, Charles C Thomas Publisher 
587 Rapalje, S., and Lawrence, R.L. (1997), A Dictionary of American and English Law, The

588 Lawbook Exchange Ltd.

589

590

591

592

593

594

595

596

597

598

599

600

601

602

603

604

605

606

607

608

609

610

611

612

613

614

615

616

617

618

619

620

621

622

623

624

625

626

627

628

629
SFO (nd) What is fraud? Available at: http://www.sfo.gov.uk/fraud/what-is-fraud.aspx http://www.sfo.gov.uk/fraud/what-is-fraud.aspx Date accessed at $28^{\text {th }}$ November 2015

Spink, J., Moyer, D.C, Park, H. and Heinonen, J.A (2013), Defining the types of counterfeiters, counterfeiting and offender organizations, Crime Science, 2:8

Spink, J. and Moyer, DC. (2013), Understanding and Combating Food Fraud, Food Technology, 67(1): 30-35.

Spink, J. and Moyer, D. C. (2011). Defining the public health threat of food fraud. Journal of Food Science 76(9): 157-163

Spink, J., Helferich, O.K., and Griggs, J.E. (2010). Combating the Impact of Product Counterfeiting. Distribution Business Management Journal 10(1), 6.

Stiborová, M., Martínek, V., Rýdlová, H., Hodek, P. and Frei, E. (2002). Sudan I is a potential carcinogen for humans. Evidence for its metabolic activation and detoxication by human recombinant cytochrome P450 1A1 and liver microsomes 1. Cancer Research, 62: 5678-5684.

USP (nd) Appendix XVII: Guidance on Food Fraud Mitigation Available at: http://www.usp.org/sites/default/files/usp_pdf/EN/fcc/Notices/guidance_on_food_fraud_miti gation.pdf [Accessed on 4th January 2016]

WHO (2002), Food Safety Issues: Terrorist Threats to Food: Guidance for Establishing and Strengthening Prevention and Response Systems 2002. ISBN 9241545844

WHO (nd), Food Security, Available at: http://www.who.int/trade/glossary/story028/en/ [Accessed on $4^{\text {th }}$ January 2016]

Walklate, S. (2007). Understanding criminology. Buckingham: Open University Press.

Wallace, C.A., Sperber, W.H., and Mortimore, S.E., (2011), Managing HACCP and Food

Safety Through the Global Supply Chain. Wiley Blackwell ISBN 9781405189118

Yang, J., Hauser, R. and Goldman, R. H. (2013). Taiwan food scandal: the illegal use of phthalates as a clouding agent and their contribution to maternal exposure. Food and Chemical Toxicology 58: 362-368. 
Table 1. Factors that can be used to assess national food system vulnerability (Source:

\section{Factors that can be used to assess national food system vulnerability}

- The effectiveness of the countries food safety management infrastructure and current surveillance mechanisms;

- Availability of potential food contamination agents;

- Motivation for perpetrators of food terrorism;

- Potential for the agent to contaminate mass produced food and gain widespread distribution;

- Potential of human-to-human transmission of the agent;

- Capability for an effective emergency response and;

- Potential size of the threat to the food supply chain, animal health and welfare, export food trade, tourism and public health.

Table 2. Types of food crime (Adapted from BRC, $2015^{1}$; Spink and Moyer, $2013^{2}$ and 636 Croall, 2009 ${ }^{3}$ )

\begin{tabular}{|c|c|c|c|}
\hline Type $^{2}$ & Definition $^{1}$ & Definition $^{2}$ & Definition $^{3}$ \\
\hline Adulteration & $\begin{array}{l}\text { The addition of an } \\
\text { undeclared material } \\
\text { into a food item for } \\
\text { economic gain. }\end{array}$ & $\begin{array}{l}\text { A component of the finished } \\
\text { product is fraudulent }\end{array}$ & Product adulteration \\
\hline Counterfeit & & $\begin{array}{l}\text { All aspects of the fraudulent } \\
\text { product and packaging are fully } \\
\text { replicated }\end{array}$ & \\
\hline Diversion & & $\begin{array}{l}\text { The sale or distribution of } \\
\text { legitimate products outside of } \\
\text { intended markets }\end{array}$ & \\
\hline Over-run & & $\begin{array}{l}\text { Legitimate product is made in } \\
\text { excess of production agreements }\end{array}$ & \\
\hline Simulation & & $\begin{array}{l}\text { Illegitimate product is designed to } \\
\text { look like but does not exactly } \\
\text { copy the legitimate product }\end{array}$ & \\
\hline Tampering & & $\begin{array}{l}\text { Legitimate product and packaging } \\
\text { are used in a fraudulent way }\end{array}$ & \\
\hline Theft & & $\begin{array}{l}\text { Legitimate product is stolen and } \\
\text { passed off as legitimately } \\
\text { procured }\end{array}$ & \\
\hline $\begin{array}{l}\text { Malicious } \\
\text { poisoning, } \\
\text { bioterrorism or } \\
\text { sabotage }\end{array}$ & & $\begin{array}{l}\text { Intentional adulteration with a } \\
\text { view to cause harm, fear or dread } \\
\text { using other types of food crime } \\
\text { identified by Spink and Moyer } \\
\text { (2013). }\end{array}$ & Food poisoning \\
\hline $\begin{array}{l}\text { Misleading } \\
\text { indications } \\
\text { (words/ } \\
\text { pictures) }\end{array}$ & & & $\begin{array}{l}\text { Use of words such as "natural", } \\
\text { "traditional". Use of pictures e.g. } \\
\text { depictions on packaging that do } \\
\text { not reflect the nature of the } \\
\text { product inside or the methods of } \\
\text { production }\end{array}$ \\
\hline $\begin{array}{l}\text { Packaging } \\
\text { size }^{2}\end{array}$ & & & Use of overlarge packaging \\
\hline
\end{tabular}




\section{Table 3. Motivation behind food fraud and food defense activities}

\begin{tabular}{|c|c|c|c|c|c|c|}
\hline $\begin{array}{c}\text { Types of } \\
\text { food crime }\end{array}$ & $\begin{array}{c}\text { Rational Choice } \\
\text { Theory (Pease, 2006) }\end{array}$ & $\begin{array}{l}\text { Routine Activity } \\
\text { Approach (Cohen } \\
\text { and Felson, 1979) }\end{array}$ & Social Control Theory (Hirschi, 1969) & $\begin{array}{c}\text { Relative } \\
\text { Deprivation } \\
\text { (Walklate, } \\
\text { 2007) }\end{array}$ & $\begin{array}{c}\text { Game-theoretic approach } \\
\text { (Hirschauer and Zwoll } \\
\text { 2008) }\end{array}$ & $\begin{array}{l}\text { Common sense } \\
\text { (Walklate 2007) }\end{array}$ \\
\hline Food fraud & $\begin{array}{l}\text { Perpetrator weighs the } \\
\text { costs and benefits of } \\
\text { committing a crime and } \\
\text { makes his or her choice. } \\
\text { In this context, choice is } \\
\text { governed by time, } \\
\text { ability and access to } \\
\text { relevant information. } \\
\text { Economic incentive as } \\
\text { pull factor }\end{array}$ & $\begin{array}{l}\text { Offenders decided } \\
\text { to commit crime } \\
\text { according to a } \\
\text { particular time, } \\
\text { targeted victims and } \\
\text { place. Categorized } \\
\text { into a triangular } \\
\text { relation - a } \\
\text { motivated offender, } \\
\text { potential victim and } \\
\text { the presence or } \\
\text { absence of a } \\
\text { guardian. It is } \\
\text { important in this } \\
\text { scenario for the } \\
\text { offender to be } \\
\text { aware of the } \\
\text { victim's routine }\end{array}$ & $\begin{array}{l}\text { Bound by fear of consequences. Social } \\
\text { controls exerted by four types of bonds. } \\
\text { Attachment level of strength or weakness } \\
\text { of relationships between an individual } \\
\text { and others as via relationships. The } \\
\text { stronger the social expectation, the } \\
\text { stronger the attachment, the more likely } \\
\text { the individual will conform. Commitment } \\
\text { i.e. conformity to a particular lifestyle. } \\
\text { The higher the level of commitment, the } \\
\text { less likely the individual will deviate } \\
\text { from it. Involvement - the time spent in } \\
\text { conventional behavior or law abiding } \\
\text { practices. The longer the time spent in } \\
\text { engaging in these activities, the less time } \\
\text { the individuals will have for other things. } \\
\text { The final bond explains that if an } \\
\text { individual had been brought up with the } \\
\text { belief that they are law abiding citizens, } \\
\text { the less likely they are to break the law. }\end{array}$ & $\begin{array}{l}\text { Occurs when an } \\
\text { individual feels } \\
\text { deprived or } \\
\text { perceive } \\
\text { themselves as } \\
\text { deprived. The } \\
\text { sense of } \\
\text { deprivation is } \\
\text { commonly (but } \\
\text { not exclusively) } \\
\text { connected to } \\
\text { material } \\
\text { circumstances } \\
\text { Economics / } \\
\text { incentives as } \\
\text { pull factor }\end{array}$ & $\begin{array}{l}\text { Reconstructs the monetary } \\
\text { incentives of profit-oriented } \\
\text { actors. The likelihood for } \\
\text { these economic actors to } \\
\text { break rules increase with the } \\
\text { probability of profits they } \\
\text { expect to earn and reduces if } \\
\text { losses are anticipated due to } \\
\text { risk of detection. At the same } \\
\text { time, fraud activities will } \\
\text { decrease with an increase in } \\
\text { social factors that could } \\
\text { 'protect' or 'shield' the profit- } \\
\text { oriented actors from yielding } \\
\text { to the economic temptation. } \\
\text { Estimates the incentives of } \\
\text { actors in farm or food } \\
\text { industries. Helps to identify } \\
\text { or expose critical settings } \\
\text { where economic temptations } \\
\text { may arise. }\end{array}$ & $\begin{array}{l}\text { Food fraud is driven by } \\
\text { monetary needs or gains } \\
\text { and / or greed. }\end{array}$ \\
\hline Food defense & $\begin{array}{l}\text { Time, ability and } \\
\text { information. Motivation } \\
\text { to do harm. }\end{array}$ & $\begin{array}{l}\text { Motivated offender } \\
\text { with a clear } \\
\text { potential victim. }\end{array}$ & No fear of consequences. & Impact oriented. & Impact oriented. & $\begin{array}{l}\text { Sadist, enjoy thrill of } \\
\text { 'excitement' caused by } \\
\text { the harm, revenge, envy. }\end{array}$ \\
\hline
\end{tabular}


Table 4. Criminal types and attributes, risk and typical countermeasures (Adapted from Spink et al. 2013)

\begin{tabular}{|c|c|c|c|}
\hline Types of Criminals & Definition & $\begin{array}{c}\text { Magnitude of risk } \\
\text { (Likelihood/Severity) }\end{array}$ & $\begin{array}{c}\text { Typical countermeasures and controls in the food supply chain to } \\
\text { mitigate risk }\end{array}$ \\
\hline $\begin{array}{l}\text { Ideological poisoning- (usually } \\
\text { single motive group or } \\
\text { individual) }\end{array}$ & $\begin{array}{l}\text { Domestic or international terrorist who } \\
\text { commits the criminal act to make an } \\
\text { ideological statement or to economically } \\
\text { harm an entity, or to create panic and fear } \\
\text { in the target population. }\end{array}$ & $\begin{array}{l}\text { Magnitude will depend on the nature of } \\
\text { the product, organization, supply chain } \\
\text { and/or the population targeted. }\end{array}$ & $\begin{array}{l}\text { Currently the use of risk assessment by organizations to identify } \\
\text { appropriate controls e.g. security, tamper evidence, supplier assurance }\end{array}$ \\
\hline $\begin{array}{l}\text { Recreational tampering and or } \\
\text { theft. }\end{array}$ & $\begin{array}{l}\text { Undertakes crime for entertainment or } \\
\text { amusement }\end{array}$ & $\begin{array}{l}\text { Low risk potentially mitigated by } \\
\text { implementing appropriate } \\
\text { countermeasures. }\end{array}$ & $\begin{array}{l}\text { Traditional technical risk assessment to implement supply chain and onsite } \\
\text { security e.g. enclosed containers, secure vehicles and containers, tamper } \\
\text { evident seals etc. }\end{array}$ \\
\hline $\begin{array}{l}\text { Occasional diversion, } \\
\text { tampering or theft }\end{array}$ & Infrequent, opportunistic individual & $\begin{array}{l}\text { Low risk potentially mitigated by } \\
\text { implementing appropriate } \\
\text { countermeasures. }\end{array}$ & $\begin{array}{l}\text { Traditional technical risk assessment to implement supply chain and onsite } \\
\text { security e.g. enclosed containers, secure vehicles and containers, tamper } \\
\text { evident seals etc. }\end{array}$ \\
\hline Occasional over-run & Infrequent, opportunistic individual & $\begin{array}{l}\text { Low risk potentially mitigated by } \\
\text { implementing appropriate } \\
\text { countermeasures. }\end{array}$ & $\begin{array}{l}\text { Stock control measures and mass balance exercises to ensure that resources } \\
\text { utilized equate to product sold legitimately on invoices, dispatch notes etc. }\end{array}$ \\
\hline $\begin{array}{l}\text { Occasional adulteration } \\
\text { (substitution) e.g. product with } \\
\text { different provenance or method } \\
\text { of production i.e. conventional } \\
\text { product sold as organic, } \\
\text { different ingredients etc. }\end{array}$ & Infrequent, opportunistic individual & $\begin{array}{l}\text { Low risk potentially mitigated by } \\
\text { implementing appropriate } \\
\text { countermeasures. }\end{array}$ & $\begin{array}{l}\text { This activity would be reactive and not systemic within the organization or } \\
\text { the food supply network. Controls will be different depending on whether } \\
\text { perpetrators are inside or outside the business and whether there is internal } \\
\text { pressure to substitute to meet supply chain requirements e.g. order size. } \\
\text { Measures such as stock control, mass balance exercises, internal audits, } \\
\text { CCTV cameras may identify but risk level increases especially if } \\
\text { adulteration cannot be identified readily by laboratory or visual analysis. }\end{array}$ \\
\hline Occupational & $\begin{array}{l}\text { Crime occurs at the place of employment, } \\
\text { either as an individual acting alone or in } \\
\text { collaboration with the modus operandi of } \\
\text { the organization }\end{array}$ & $\begin{array}{l}\text { Magnitude of risk increases especially } \\
\text { if individual can operate unnoticed in } \\
\text { an organization or operates in } \\
\text { collaboration with the organization. } \\
\text { Potentially a degree of mitigation by } \\
\text { implementing appropriate } \\
\text { countermeasures unless the activity is } \\
\text { deliberately ignored or encouraged by } \\
\text { management. }\end{array}$ & $\begin{array}{l}\text { Crime occurs at the place of employment, either lone individuals or } \\
\text { through collaboration with the modus operandi of the organization. } \\
\text { Perpetrators understand the controls and countermeasures in place and are } \\
\text { able to work around them falsifying documentation if necessary }\end{array}$ \\
\hline Professional & $\begin{array}{l}\text { Criminal activity fully finances their } \\
\text { lifestyle }\end{array}$ & $\begin{array}{l}\text { Magnitude of risk increases and will } \\
\text { depend on the nature of the product, } \\
\text { organization, supply chain and/or the } \\
\text { population targeted. }\end{array}$ & $\begin{array}{l}\text { Existing measures and controls in place can be vulnerable to professional } \\
\text { criminals and their networks }\end{array}$ \\
\hline
\end{tabular}


Table 5. Root cause analysis of intentional food adulteration (Adapted from Motarjemi and Wallace, 2014).

\begin{tabular}{|c|c|c|c|}
\hline & Food fraud & Food Defense (internal employee) & $\begin{array}{c}\text { Food Defense (external agent) } \\
\end{array}$ \\
\hline \multirow[t]{2}{*}{1} & Why was the fraud committed? & $\begin{array}{l}\text { Why did the employee deliberately adulterate the } \\
\text { product? }\end{array}$ & $\begin{array}{l}\text { Why did the agent deliberately adulterate the } \\
\text { product? }\end{array}$ \\
\hline & $\begin{array}{l}\text { Motivated for monetary gain. Deliberately modifying } \\
\text { the food to achieve more } \$\end{array}$ & Motivated to harm or insinuate harm had been caused. & Motivated to harm, publicity, other motive \\
\hline \multirow[t]{2}{*}{2} & Why did the agent want monetary gain? & Why did the employee want to bring harm? & Why did the agent want to bring harm? \\
\hline & $\begin{array}{l}\text { Motivation to access money especially if perpetrator } \\
\text { can identify a vulnerability }\end{array}$ & $\begin{array}{l}\text { Revenge, dissatisfaction, excitement in causing chaos, } \\
\text { financial gain e.g. blackmail, }\end{array}$ & $\begin{array}{l}\text { Revenge, dissatisfaction, envy (competitor), excitement } \\
\text { in causing chaos, financial gain e.g. blackmail }\end{array}$ \\
\hline \multirow[t]{2}{*}{3} & Why did the agent target this organization? & Why did the employee feel dissatisfy or resentful? & Why did the agent target this organization? \\
\hline & $\begin{array}{l}\text { Ability to perpetrate the crime without discovery, } \\
\text { magnitude of financial gain compared to risk. }\end{array}$ & Unjust work-related practices, termination, personal grudge & $\begin{array}{l}\text { Unjust business-related practices, personal grudge, ability } \\
\text { to gain publicity due to organization's profile. }\end{array}$ \\
\hline \multirow[t]{2}{*}{4} & $\begin{array}{l}\text { Why did illicit business related practices arise? } \\
\text { What is it about the organization's profile that } \\
\text { draws attention? }\end{array}$ & $\begin{array}{l}\text { Why was the employee terminated? Why did unjust } \\
\text { work-related practices arise in the company? }\end{array}$ & $\begin{array}{l}\text { Why did unjust business-related practices arise with } \\
\text { the company? What is it about the organization's } \\
\text { profile that draws attention? }\end{array}$ \\
\hline & $\begin{array}{l}\text { In order to answer the above specific questions, the } \\
\text { respective organization can investigate reasons e.g. } \\
\text { vulnerability to fraud, networks in which the business } \\
\text { operates etc. }\end{array}$ & $\begin{array}{l}\text { In order to answer the above specific questions, the } \\
\text { respective organization can investigate if the above claims } \\
\text { are true and find ways to resolve unjust work-related } \\
\text { practices. }\end{array}$ & $\begin{array}{l}\text { In order to answer the above specific questions, the } \\
\text { respective organization can investigate reasons e.g. } \\
\text { country of origin of organization, religious or ideological } \\
\text { background, previous business practice that could warrant } \\
\text { organization being seen as unjust. }\end{array}$ \\
\hline \multirow[t]{2}{*}{5} & How should the company react? & How should the company react? & How should the company react? \\
\hline & $\begin{array}{l}\text { Investigate the incident and identify vulnerabilities } \\
\text { through the use of an appropriate analysis tool }\end{array}$ & $\begin{array}{l}\text { Change of keys /access number to reduce accessibility, } \\
\text { security and utilization of threat analysis tool }\end{array}$ & $\begin{array}{l}\text { Change of keys /access number to reduce accessibility, } \\
\text { security and utilization of CARVER + Shock tool }\end{array}$ \\
\hline \multirow[t]{2}{*}{6} & $\begin{array}{l}\text { How proactive should the company be to reduce } \\
\text { future risk of threats }\end{array}$ & $\begin{array}{l}\text { How proactive should the company be to reduce future } \\
\text { internal food threats? }\end{array}$ & $\begin{array}{l}\text { How proactive should the company be to reduce } \\
\text { future external food threats? }\end{array}$ \\
\hline & $\begin{array}{l}\text { Adopt proactive approach to improve work related } \\
\text { practices and conditions and utilization of appropriate } \\
\text { analysis tool. }\end{array}$ & $\begin{array}{l}\text { Adopt proactive approach to improve work related practices } \\
\text { and conditions and utilization of threat analysis tool. }\end{array}$ & $\begin{array}{l}\text { Adopt proactive approach to improve work and supply } \\
\text { chain related practices and conditions and utilization of } \\
\text { threat analysis tool. }\end{array}$ \\
\hline
\end{tabular}


Table 6. Comparison of existing FCRA models

\begin{tabular}{|c|c|c|c|c|c|c|}
\hline & $\begin{array}{l}\text { Threat Assessment } \\
\text { Critical Control Point } \\
\text { (TACCP) }\end{array}$ & $\begin{array}{l}\text { Vulnerability } \\
\text { Assessment and } \\
\text { Critical Control } \\
\text { Point (VACCP) } \\
\end{array}$ & $\begin{array}{l}\text { Food Protection Risk Matrix } \\
\text { (Spink and Moyer 2011) }\end{array}$ & $\begin{array}{c}\text { NSF Fraud } \\
\text { Protection Model } \\
\text { (NSF, 2014) }\end{array}$ & $\begin{array}{l}\text { USP Preventive Food } \\
\text { Fraud Management } \\
\text { System (USP, nd) }\end{array}$ & CARVER + Shock Tool (US FDA) \\
\hline Aims & $\begin{array}{l}\text { To assess threats and } \\
\text { prevent behaviorally or } \\
\text { ideologically motivated } \\
\text { intentional adulteration } \\
\text { (Leathers 2014) }\end{array}$ & $\begin{array}{l}\text { To assess how } \\
\text { exposed/ } \\
\text { susceptible } \\
\text { organization or } \\
\text { premise is to food } \\
\text { fraud incidents. } \\
\text { Prevention of } \\
\text { intentional EMA } \\
\text { (Spink 2014) } \\
\end{array}$ & $\begin{array}{l}\text { To differentiate food fraud } \\
\text { among other food control } \\
\text { elements such as food safety, } \\
\text { food defense and food quality. }\end{array}$ & $\begin{array}{l}\text { To better anticipate } \\
\text { the likelihood of } \\
\text { fraudulent attack on } \\
\text { food products } \\
\text { especially according } \\
\text { to product value. }\end{array}$ & $\begin{array}{l}\text { To assist users in how to } \\
\text { develop and implement a } \\
\text { preventive system } \\
\text { specifically for the } \\
\text { adulteration of food } \\
\text { ingredients. }\end{array}$ & $\begin{array}{l}\text { Allows user to think like an attacker and to determine the most } \\
\text { vulnerable point within a system or premise to an attack. } \\
\text { To focus resources on protecting the most susceptible points in } \\
\text { the system. }\end{array}$ \\
\hline Mechanisms & $\begin{array}{l}\text { Qualitative assessments } \\
\text { (likelihood x impact) of } \\
\text { threats }\end{array}$ & $\begin{array}{l}\text { Qualitative } \\
\text { assessments } \\
\text { (likelihood } x \\
\text { impact) of threats }\end{array}$ & $\begin{array}{l}\text { Risk matrix is designed to } \\
\text { identify the cause of risk and the } \\
\text { motivations driving the fraud } \\
\text { but not the effect. }\end{array}$ & $\begin{array}{l}\text { Built on a } 4 \text { quadrant } \\
\text { Boston Consulting } \\
\text { Group (BCG) } \\
\text { matrix. } \\
\text {-Top right = } \\
\text { products most } \\
\text { attractive to } \\
\text { fraudster } \\
\text {-Bottom left = least } \\
\text { attractive to } \\
\text { fraudster } \\
\text {-Size of circle of a } \\
\text { food product } \\
\text { represents the } \\
\text { perceived difficulty } \\
\text { of conducting the } \\
\text { fraud. }\end{array}$ & $\begin{array}{l}\text { Structured approach to } \\
\text { characterize food fraud } \\
\text { vulnerabilities with } \\
\text { associated guidance to } \\
\text { develop mitigation } \\
\text { strategies. } \\
\text { Nine contributing factors } \\
\text { considered and how they } \\
\text { impact on vulnerability } \\
\text { using a matrix approach. } \\
\text { Lifecycle approach } \\
\text { proposed for food fraud } \\
\text { management. }\end{array}$ & $\begin{array}{l}\text { Based on seven attributes which are scored on a scale of 1-10 } \\
\text { (FDA 2014) } \\
\text { - Criticality - measure of public health and economic impacts } \\
\text { of an attack } \\
\text { - Accessibility - ability to physically access and egress from } \\
\text { target } \\
\text { - Recuperability - ability of system to recover from an attack } \\
\text { - Vulnerability - ease of accomplishing attack } \\
\text { - } \quad \text { Effect - amount of direct loss from an attack as measured } \\
\text { by loss in production } \\
\text { - Recognizability - ease of identifying target } \\
\text { - Shock - combined health, economic, and psychological } \\
\text { impacts of an attack. } \\
\text { provides relative risk rankings for nodes / process steps in a } \\
\text { production process or national food system. }\end{array}$ \\
\hline Practicalities & $\begin{array}{l}\text { Likelihood and impact } \\
\text { scores and use of priority } \\
\text { matrix in TACCP } \\
\text { provides hierarchy for } \\
\text { action by risk for } \\
\text { organizations. } \\
\text { Assess threats within } \\
\text { manufacturing } \\
\text { environment or within an } \\
\text { organization but will be } \\
\text { difficult to assess } \\
\text { suppliers i.e. prior to } \\
\text { delivery (Marsh 2015) }\end{array}$ & $\begin{array}{l}\text { Can be used in the } \\
\text { wider supply } \\
\text { chain. }\end{array}$ & $\begin{array}{l}\text { The four quadrants in the matrix } \\
\text { assist in exploring criteria } \\
\text { Food quality - may be caused } \\
\text { by mishandling } \\
\text { Food safety - may be caused by } \\
\text { unintentional contamination } \\
\text { Food fraud - intentionally done } \\
\text { to increase profit margin } \\
\text { Food defense - deliberately } \\
\text { carried out to cause harm (Spink } \\
\text { and Moyer, 2011) }\end{array}$ & $\begin{array}{l}\text { Food industries and } \\
\text { regulatory teams can } \\
\text { use the model to } \\
\text { anticipate which } \\
\text { products are most } \\
\text { likely to be targeted } \\
\text { by fraudsters, the } \\
\text { factors for targeting } \\
\text { and whether } \\
\text { previous frauds had } \\
\text { occurred. }\end{array}$ & $\begin{array}{l}\text { Four step process. First } \\
\text { three characterize fraud } \\
\text { vulnerabilities associated } \\
\text { with an ingredient by } \\
\text { considering occurrence } \\
\text { and impact. Last step is } \\
\text { guidance. }\end{array}$ & $\begin{array}{l}\text { Critical or vulnerable nodes / process steps are identified based } \\
\text { on the scores. } \\
\text { Prioritize mitigation measures and resources to reduce } \\
\text { likelihood of attack. } \\
\text { Another option in CARVER + Shock would be to only use the } \\
\text { Criticality, Accessibility and Vulnerability (CAV) scores and } \\
\text { facility or process line level. }\end{array}$ \\
\hline $\begin{array}{l}\text { Suggestions / } \\
\text { Extensions }\end{array}$ & $\begin{array}{l}\text { To assess both threats al } \\
\text { combined under one sys } \\
\text { and vulnerability assessn } \\
\text { under one management sy }\end{array}$ & $\begin{array}{l}\text { vulnerabilities and } \\
\mathrm{m} \text {. Combine threat } \\
\text { th and manage risk } \\
\mathrm{m} \text {. }\end{array}$ & & & & \\
\hline
\end{tabular}




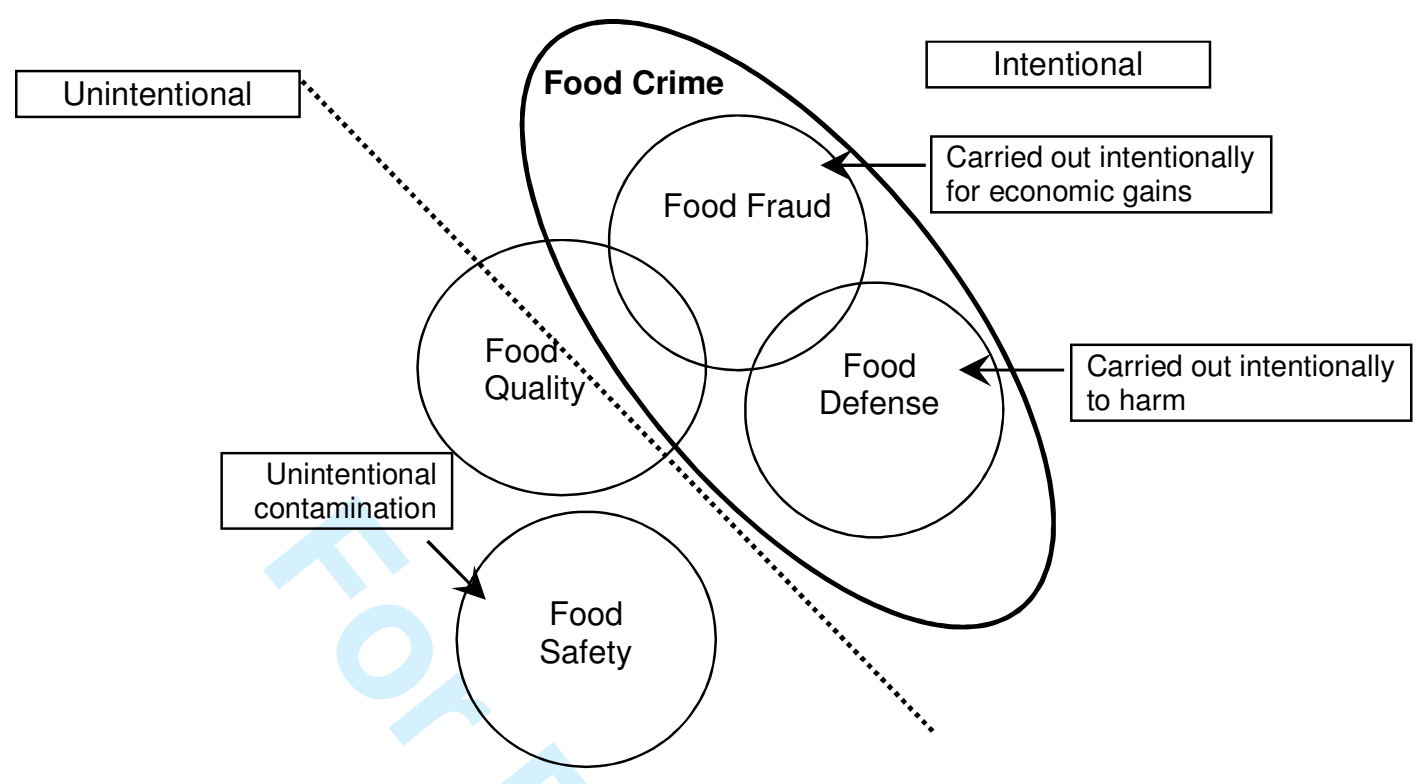

Figure 1. Intentional and unintentional modifications of food (food fraud, defense, safety and quality) that need to be addressed in a food control system. (Adapted from GFSI, 2014; FSIS, 2014; Leathers, 2014; Spink and Moyer, 2011)

\begin{tabular}{|c|c|c|}
\hline Unintentional & Intentional & Motivation \\
\hline $\begin{array}{c}\text { Food } \\
\text { Quality }\end{array}$ & $\begin{array}{c}\text { Food } \\
\text { Fraud }\end{array}$ & Economic gain \\
\hline $\begin{array}{c}\text { Food } \\
\text { Safety }\end{array}$ & Food Defense & Harm \\
\hline
\end{tabular}

Figure 2. The food protection risk matrix (Adapted from Spink and Moyer, 2011)

\begin{tabular}{|c|c|}
\hline $\begin{array}{c}\text { High profit: high likelihood of } \\
\text { detection } \\
\text { Medium food fraud risk }\end{array}$ & $\begin{array}{c}\text { High profit: low likelihood of } \\
\text { detection } \\
\text { High food fraud risk }\end{array}$ \\
\hline $\begin{array}{c}\text { Low profit: high likelihood of } \\
\text { detection } \\
\text { Low food fraud risk }\end{array}$ & $\begin{array}{c}\text { Low profit: low likelihood of } \\
\text { detection } \\
\text { Low food fraud risk }\end{array}$ \\
\hline
\end{tabular}

Figure 3. Food fraud quadrant model (Adapted from NSF, 2015) 